\title{
THERMAL COMFORT TEMPERATURE UPDATE FOR BROILER CHICKENS UP TO 21 DAYS OF AGE ${ }^{1}$
}

\author{
DÉBORAH C. CASSUCE ${ }^{2}$, ILDA DE F. F. TINÔCO ${ }^{3}$, FERNANDO C. BAÊTA ${ }^{4}$, \\ SÉRGIO ZOLNIER ${ }^{5}$, PAULO R. CECON ${ }^{6}$, MARIA DE F. A. VIEIRA ${ }^{7}$
}

\begin{abstract}
Due to changes in genetics and nutrition, as well as in acclimatization of broiler chickens to the Brazilian climate, temperature values currently accepted as optimal may be outdated. The objective of this research was to update the environment temperatures that characterize the thermal comfort for broilers chickens from one to 21 days of age, under Brazilian production conditions. This research was conducted with 600 COBB birds, which were distributed in five growth chambers maintained at different temperatures during the first three weeks of age. During the experimental period, temperature values were progressively reduced, consisting in five treatments: T2724/21, T30/27/24, T33/30/27, T36/33/30 and T39/36/33. It was observed that the birds maintained in the $\mathrm{T} 30_{27-24}$ treatment presented better performance compared to other environment conditions. Based on the obtained regression models, the environment temperature values that provide greater weighing gain for the broiler chicken growth in the initial period were $31.3,25.5$ and $21.8^{\circ} \mathrm{C}$, respectively for the first, second and third week of age.
\end{abstract}

KEYWORDS: thermal stress, aviculture, performance.

\section{ATUALIZAÇÃO DAS TEMPERATURAS DE CONFORTO TÉRMICO PARA FRANGOS DE CORTE DE ATÉ 21 DIAS DE IDADE}

RESUMO: Em decorrência de alterações na genética e nutrição, bem como na aclimatização das aves de corte ao clima do Brasil, as temperaturas atualmente preconizadas como ótimas para criação podem estar defasadas. Objetivou-se com esta pesquisa atualizar os valores de temperatura ambiente que caracterizam o conforto térmico para frangos de corte de um a 21 dias de idade, sob condições brasileiras de produção. Esta pesquisa foi conduzida com 600 aves da linhagem COBB, que foram distribuídas em cinco câmaras climáticas, mantidas sob diferentes temperaturas, durante as três primeiras semanas de idade. Durante o período experimental, os valores de temperatura média para as semanas de um a três foram reduzidos progressivamente, constituindo-se de cinco tratamentos: T27/24/21; T30/27/24; T33/30/27; T36/33/30 e T39/36/33. Verificou-se que as aves mantidas sob o tratamento $\mathrm{T}_{30} 27-24$ apresentaram melhor desempenho zootécnico quando comparadas às demais condições ambientes. Com base nos modelos de regressão obtidos, os valores de temperatura ambiente que proporcionam o maior ganho de peso para o período inicial de criação de frangos de corte foram 31,$3 ; 25,5$ e $21,8^{\circ} \mathrm{C}$, respectivamente, na primeira, segunda e terceiras semanas de vida dos animais.

PALAVRAS-CHAVE: estresse térmico, avicultura, desempenho.

\footnotetext{
${ }^{1}$ Part of the $\mathrm{PhD}$ thesis of the first author.

${ }^{2}$ Profa. de Ensino Básico, Técnico e Tecnológico DIII, Instituto Federal do Mato Grosso, Câmpus Campo Novo do Parecis - MT, deborah.cassuce@cnp.ifmt.edu.br.

${ }^{3}$ Profa. Associada III, Universidade Federal de Viçosa - MG, iftinoco@ufv.br.

${ }^{4}$ Prof. Titular, Universidade Federal de Viçosa - MG, baeta@ufv.vr.

${ }^{5}$ Prof. Adjunto, Universidade Federal de Viçosa - MG, zolnier@ufv.br.

${ }^{6}$ Prof. Associado IV, Universidade Federal de Viçosa - MG, cecon@ufv.br.

${ }^{7}$ Doutorada em Engenharia Agrícola, Universidade Federal de Viçosa - MG, maria.vieira@ufv.br.

Recebido pelo Conselho Editorial em: 12-3-2012

Aprovado pelo Conselho Editorial em: 17-9-2012
} 


\section{INTRODUCTION}

According to VENCATO (2011), Brazil is the third largest producer of chicken meat, only behind China and the United States. The enormous global and national growth in poultry farming was due mainly to developments in the areas of genetics, nutrition, management and health, as well as offering the most suitable environments to the thermal comfort of the animals.

Admittedly, the broiler rely on thermally comfortable environment to express their production potential, so they need to remain under appropriate temperature and humidity values during each stage of growth. In high temperature conditions, the animals require physical mechanisms such as evaporative cooling and reduction of food consumption to maintain constant body temperature (WELKER et al., 2008).

To establish good growth parameters, several authors on researches almost entirely carried out in temperate climates, have been setting the temperature bands considered as optimal environments for the growth of broilers, aiming at more productive performance. These temperature bands, in one form or another has guided the way of growth and using thermal conditioning systems for heat and cold in Brazil. These bands, adapted from studies done by some authors for various ages of broilers, are presented in Table 1.

TABLE 1. Comfort temperature bands for broiler chicken of different ages.

\begin{tabular}{cc}
\hline Age $($ Week $)$ & Temperature Bands $\left({ }^{\circ} \mathrm{C}\right)$ \\
\hline 1st & $34-32$ \\
2nd & $32-28$ \\
3rd & $28-26$ \\
4th & $26-24$ \\
5th & $18-24$ \\
6th & $18-24$ \\
\hline
\end{tabular}

Adapted from FREEMAN (1968); MACARI et al. (2002); AVILA (2004).

These comfortable temperature values, however, will suffer changes due to genetic evolution of species, growth means and management, housing density, severity of thermal stress to which the animals are subjected, thus allowing adaptation and acclimatization of species to environmental specific conditions of different climatic regions of the world.

The stress caused by thermal environment influences endocrinology and physiology of the poultry, and, consequently, productivity, by changing their heat exchange with the environment and modify the rate of food consumption, the rate of body weight gain and the nutritional requirements (SOUZA et al., 2011; BARBOSA et al., 2008).

The evaluation of production performance in relation to environmental conditions offered is accomplished through analysis of performance indexes, such as feed intake of the birds, total weight gain, feed conversion, average body weight and mortality rate (CARVALHO et al., 2009; ROCHA et al., 2010).

Based on the temperature bands considered as optimal in accordance with the literature, the temperature values currently considered as comfortable for broilers may be outdated due to changes in genetics, nutrition, environmental and growth management, among other factors.

Given the above, the development of researches that investigate, evaluate and establish the best temperature range for broilers acclimated in the country is essential. The development of such studies is important in the initial, intermediate and final stages, aiming at optimizing the cost of energy used in heating and cooling thermal environment.

The objective of this study was to evaluate the temperature values recommended as thermal comfort for the initial period of growth of broilers in Brazil, including the period from one to 21 
days of age, from the evaluation of the performance of broilers submitted to different conditions of air temperature in climatic chambers.

\section{MATERIAL AND METHODS}

The study was conducted in five climatic chambers with dimensions of $2.5 \times 3.3 \times 2.5 \mathrm{~m}$, from the Center for Research in Ambience and Agroindustrial Engineering - AMBIAGRO, based in the Department of Agricultural Engineering, Federal University of Viçosa, Brazil.

The research was conducted with broilers from one to 21 days of age in a period characterized by the need of heating of the growth environment.

It was used 600 one-day old Cobb male broiler chickens, with an average weight of $40.28 \pm 0.33 \mathrm{~g}$ from the same farm, which were randomly distributed in the five chambers.

Each chamber had six cages with dimensions of $0.5 \mathrm{~m} \times 1.0 \mathrm{~m} \times 0.5 \mathrm{~m}, 0.70 \mathrm{~m}$ from the ground, in which they initially housed 20 birds from one day of age with subsequent reduction to 15 birds at the beginning of the third week of growth. The broilers were selected by body weight, and those with extreme weights were excluded. This procedure was adopted to ensure the density used by the poultry industry for different ages.

Considering the need of gradually reducing the air temperature in the first three weeks of age of the broilers, it was advocated five thermal conditions, which were implemented in each of the chambers, as shown below:

T27/24/21: temperatures of 27,24 and $21^{\circ} \mathrm{C}$ respectively for the first, second and third week of accommodation. This environment is characterized as sharp cold;

T30/27/24: temperatures of 30,27 and $24^{\circ} \mathrm{C}$ respectively for the first, second and third week, established as moderate cold;

T33/30/27: temperatures of 33,30 and $27^{\circ} \mathrm{C}$ respectively for the first, second and third week, understood as thermal comfort;

T36/33/30: temperatures of 36,33 and $30^{\circ} \mathrm{C}$ respectively for the first, second and third week, characterized as moderate heat;

T39/36/33: temperatures of 39,36 and $33{ }^{\circ} \mathrm{C}$ respectively for the first, second and third week, established as sharp heat.

The relative humidity inside the chambers, for all treatments was maintained at around $60 \%$. According to TINOCO (2004), this value can be considered suitable for poultry production, regardless of the age of the broilers.

The supply of water and food was carried out without restrictions, keeping the drinkers and feeders always full. Pre-starter commercial ration was provided (broilers from one to seven days) and starter commercial ration (for broilers of eight to 21 days of age).

The photoperiod control program followed the pattern used in the poultry industry, adopting a one-hour dark period for birds of one to four days of age and 11 hours of dark period thereafter.

The desired values of temperature and relative humidity within each climate chamber, in accordance with previous treatments, were automatically maintained using a microcontroller. These variables were also continuously recorded throughout the experimental period, using dataloggers that had integrated sensors for temperature and relative humidity, presenting resolutions of $0.1{ }^{\circ} \mathrm{C}$ and $2 \%$, respectively (Table 2 ). 
TABLE 2. Applied values of temperature, relative humidity and BGHI within the chambers of each treatment (T27/24/21, T30/27/24, T33/30/27, T36/33/30, T39/36/33) during the first stage of the study.

\begin{tabular}{lccccc}
\hline & $\mathrm{T} 27 / 24 / 21$ & $\mathrm{~T} 30 / 27 / 24$ & $T 33 / 30 / 27$ & $\mathrm{~T} 36 / 33 / 30$ & $\mathrm{~T} 39 / 36 / 33$ \\
\hline \multicolumn{5}{c}{$1^{\text {st }} \mathrm{Week}$} \\
\hline Room temperature $\left({ }^{\circ} \mathrm{C}\right)$ & $27 \pm 0.3$ & $30 \pm 0.3$ & $33 \pm 0.3$ & $36 \pm 0.3$ & $39 \pm 0.4$ \\
Relative humidity $(\%)$ & $62 \pm 5.1$ & $61.3 \pm 7.3$ & $63.2 \pm 5$ & $65.1 \pm 8.1$ & $60 \pm 8$ \\
\hline \multicolumn{5}{c}{$2^{\text {nd }}$ Week } \\
\hline Room temperature $\left({ }^{\circ} \mathrm{C}\right)$ & $24 \pm 0.7$ & $27 \pm 0.4$ & $30 \pm 0.5$ & $33 \pm 0.3$ & $36 \pm 0.3$ \\
Relative humidity $(\%)$ & $61.8 \pm 5.7$ & $65.4 \pm 4.9$ & $68.3 \pm 4.2$ & $62.1 \pm 5$ & $57.1 \pm 5$ \\
\hline \multicolumn{5}{c}{$3^{\text {rd }}$ Week } \\
Room temperature $\left({ }^{\circ} \mathrm{C}\right)$ & $21 \pm 0.8$ & $24 \pm 1.4$ & $27 \pm 0.7$ & $30 \pm 0.5$ & $33 \pm 0.5$ \\
Relative humidity $(\%)$ & $61.4 \pm 4$ & $66.2 \pm 6$ & $60.6 \pm 4.6$ & $61.2 \pm 4.9$ & $56.2 \pm 4.9$ \\
\hline
\end{tabular}

The hygienic ventilation promoted within the chambers was implemented from axial blowers, with automatic activation, to allow three, four and five air changes per hour, respectively in the first, second and third week of life of the poultry.

It was recorded weekly data of weight gain (GP), in $\mathrm{g}$, feed intake (CR), in $\mathrm{g}$, and feed conversion (CA) in $\mathrm{g} / \mathrm{g}$.

Feed intake during the experimental period was calculated from the difference between the feed provided and the surplus available in the feeders.

The mortality was daily registered and calculated in relation to the number of broilers at the beginning of each week of the study.

Treatments were randomly applied in the five climate chambers available. The broilers were randomly assigned to six cages per treatment, making the repetitions. The broiler weekly performance data were subjected to regression analysis to $1 \%$ significance by " $t$ " test. The carcass data were tested by the Dunnett's test, at a 5\% probability, with the objective of comparing the control treatment (such as thermal comfort temperatures according to the literature) with the others (as recommended temperatures for different levels of discomfort).

The observed data were submitted to analysis of variance using the Statistical Analysis System and Genetics - SAEG (EUCLYDES, 2005).

\section{RESULTS AND DISCUSSION}

The significant effect $(\mathrm{P}<0.01)$ by the $\mathrm{F}$ test for different treatments (different thermal environments) on the average results of weight gain - GP (C.V. $=2.95 \%, 3.38 \%$ and $5.48 \%$, respectively, in the three weeks of life), feed conversion - CA (C.V. $=2.96 \%, 3.57 \%$ and $5.83 \%$ respectively, in the three weeks of life) and body weight - PC (C.V. $=2.31 \%, 2.29 \%$ and $2.59 \%$, respectively, within three weeks of life).

\section{Weight gain and room temperature}

Based on regression analysis, it was found that the estimated weight gain of the animals for each of the three first weeks of life was influenced significantly and quadratically by the room temperature, as illustrated in Figure 1.

The highest weight gain of broilers during the first weeks of life (145.48 g) was estimated by the regression equation with a temperature of $31.3{ }^{\circ} \mathrm{C}$. 

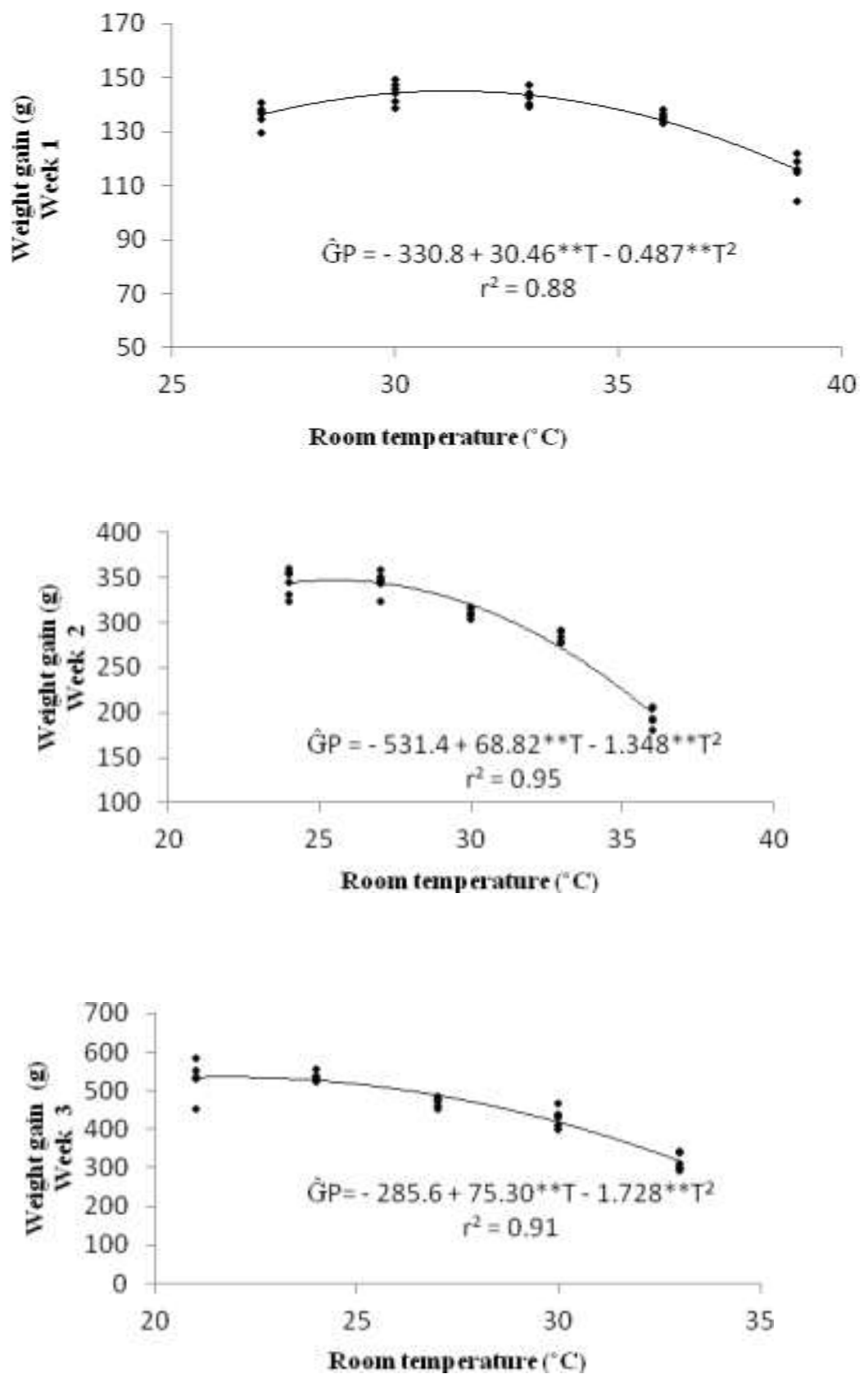

$(2 \mathrm{C})$

FIGURE 1. Estimating the effect of temperature on the weight gain of the first week (2A), second week (2B) and third week (2C) of life. T - Temperature; * at a 5\% probability.

It can be observed that broilers, kept in that temperature, had values of weight gain close to those maintained at $33{ }^{\circ} \mathrm{C}(144.03 \mathrm{~g})$. Thus, there can be reduced $2.7^{\circ} \mathrm{C}$ in room temperature, relative to that ideal as hitherto understood, resulting in energy savings for heating in the initial growth without compromising broilers performance. However, SILVA et al. (2009) reported values of weight gain of the broilers in the first phase of growth, $12 \%$ higher when kept at temperature of $31.4^{\circ} \mathrm{C}$, compared to those maintained at $34 \pm 1{ }^{\circ} \mathrm{C}$.

Based on regression equation obtained, there is, for the second week of life of the poultry, that the highest weight gain occurs in the room temperature of $25.5^{\circ} \mathrm{C}$, or $4.5^{\circ} \mathrm{C}$ below the comfort advocated the literature $\left(30^{\circ} \mathrm{C}\right)$. However, from this point, there is a reduction in weight gain with increasing temperature. These results differ from those found by MAY \& LOTT (2000), who found higher values of weight gain of male chicks during the second week of growth, for the temperature range of between $25.8^{\circ} \mathrm{C}$ and $27.9^{\circ} \mathrm{C}$ and the results of SILVA et al. (2009), who observed higher values of weight gain at $28 \pm 2{ }^{\circ} \mathrm{C}$. 
Already during the third week of life of the broilers, the animals showed greater weight gain estimated by the regression equation when exposed to room temperature of $21.8^{\circ} \mathrm{C}$.

\section{Feed conversion and room temperature}

The estimated feed conversion was significantly influenced by the temperature in each of the first three weeks of life tested, varying quadratically as illustrated in Figure 2.
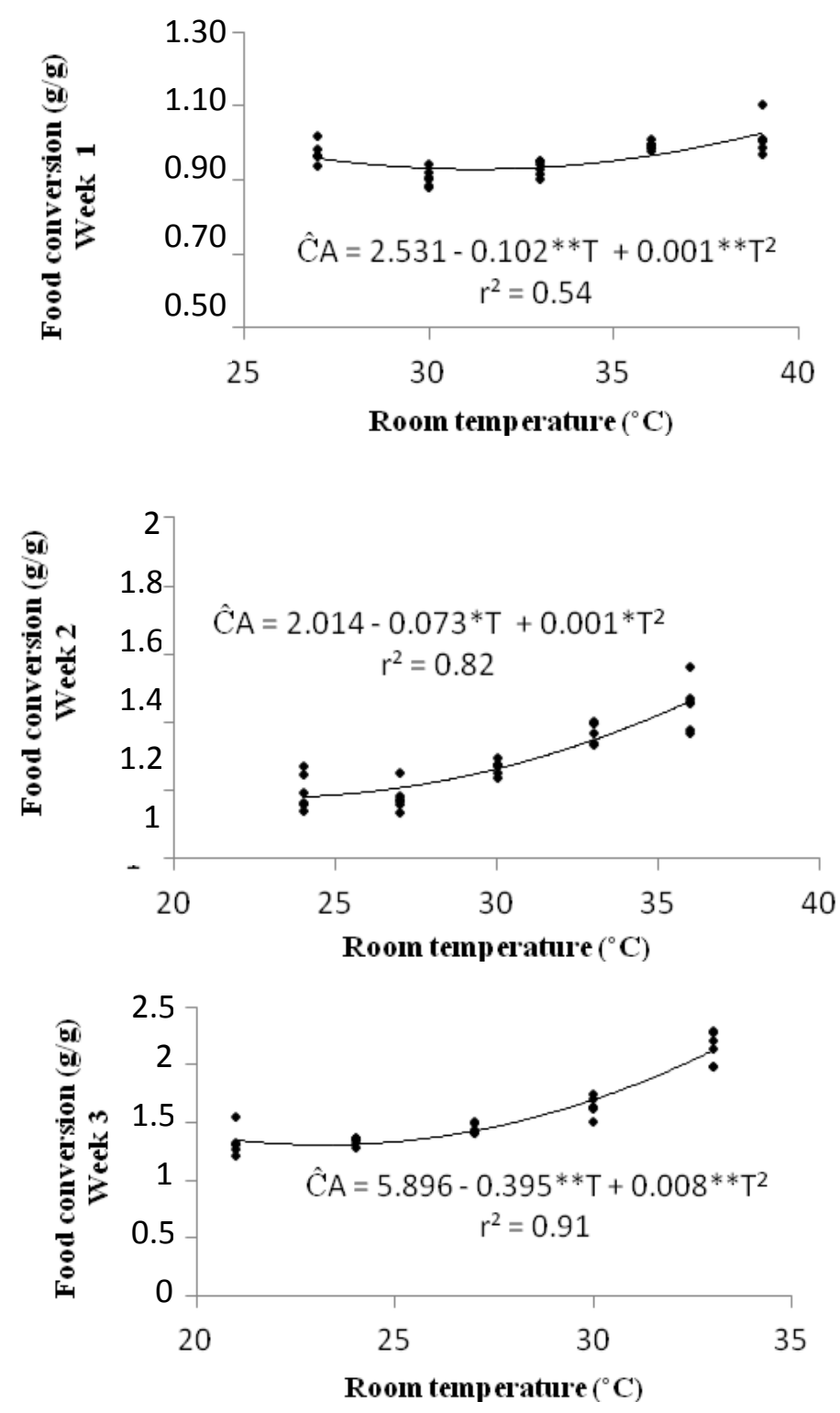

FIGURE 2. Estimated effect of temperature on feed conversion of broilers in the first week (3A), second week (3B) and third week (3C) of life. T - Temperature; *at a 5\% probability.

Based on regression equation shown in Figure 2, it is observed that the lowest value of feed conversion during the first week of life of the poultry has been obtained at $31.3{ }^{\circ} \mathrm{C}$, i.e., below the temperature recommended as thermal comfort for this period $\left(33^{\circ} \mathrm{C}\right)$. Starting at $31.3{ }^{\circ} \mathrm{C}$, higher or lower values of temperature demand deviation of the energy consumed by the broilers to maintain constant body temperature, resulting in losses in productive performance.

During the second week of the animals' life, it is possible to observe, based on the regression equation, the best feed conversion value can be obtained when the broilers are housed at room temperature of $27.1^{\circ} \mathrm{C}$. Thus, it is possible to state that the feed intake increase by the broilers subjected to temperatures below this value was used primarily for increasing calories for maintaining homeothermy, and not to weight gain. Antagonistically, above $27.1^{\circ} \mathrm{C}$, the worst feed 
conversion can be explained by a reduction in feed consumption, accompanied by a drastic reduction in weight gain, because of the attempt by the animal to reduce the production of endogenous heat to maintain homeothermy. Therefore, it can be inferred that the temperature recommended by the literature as thermal comfort for broilers during the second week of life actually are not consistent with the ideal thermal conditions for maximum production performance.

In the third week of the broiler's life, the lowest value of feed conversion estimated by the regression equation was obtained at a temperature of $23.2^{\circ} \mathrm{C}$. Again, it was found that temperature bands of comfort, heretofore proposed, are above those really best suited to the performance of broiler chickens of all ages.

SILVA et al. (2009) also observed increased feed conversion in broilers subjected to heat stress $\left(31 \pm 3{ }^{\circ} \mathrm{C}\right)$ compared to those kept in thermal comfort conditions $\left(28 \pm 2{ }^{\circ} \mathrm{C}\right)$ during the second week of life.

\section{Body weight and room temperature}

Figure 3 shows the effect of room temperature on body weight of the broilers. It is noted that the temperature significantly influenced the body weight of each animal during the first three weeks evaluated.
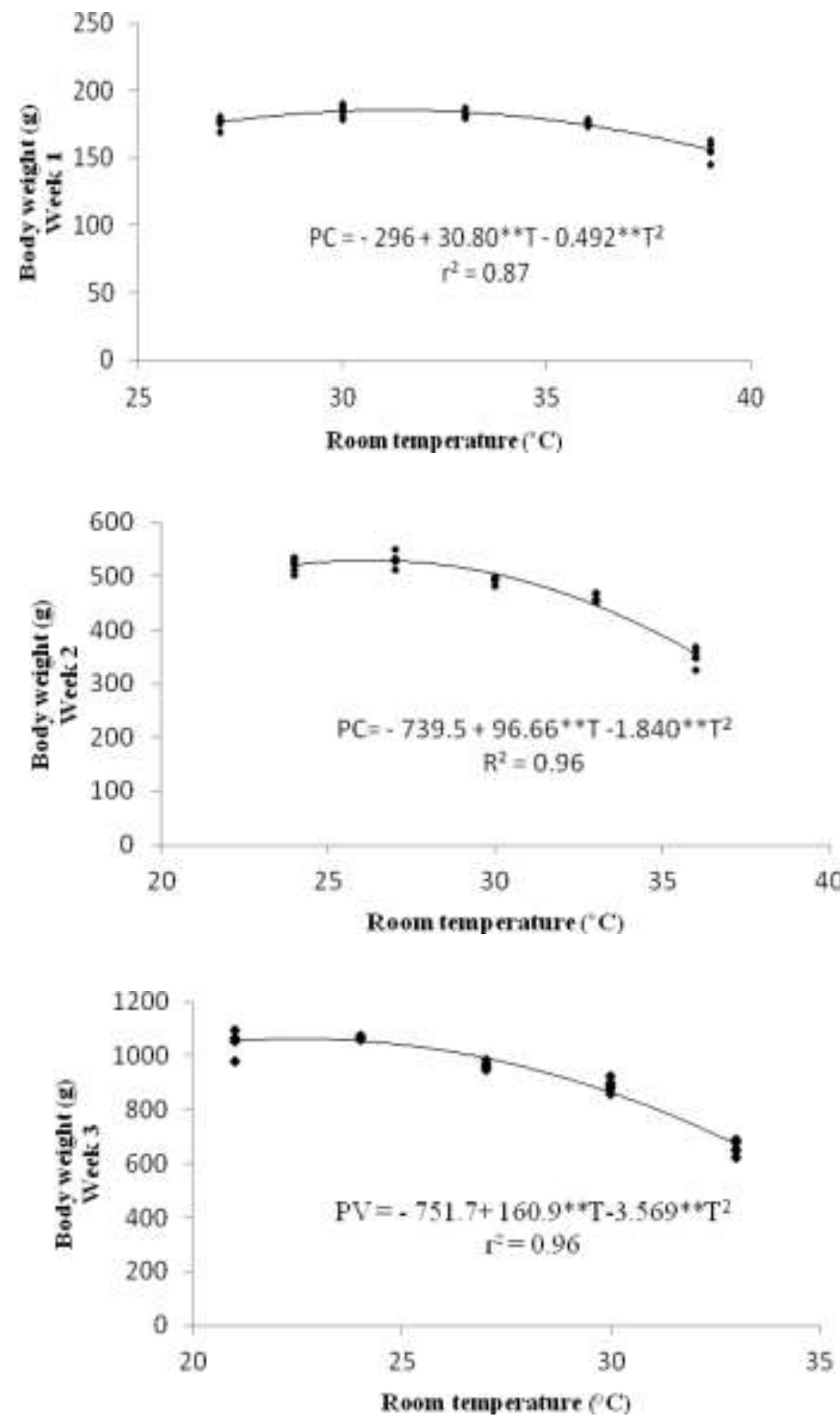

FIGURE 3. Effect of temperature on the body weight values of the first week (4A), second week (4B) and third weeks (4C) of life. T - Temperature; *at a 5\% probability. 
The highest estimated values of body weights of broilers were observed at temperatures of 31.3, 26.3 and $22.5{ }^{\circ} \mathrm{C}$ respectively for the first, second and third week of life of broilers, which are close to those considered ideal according to the literature, for this period of growth.

\section{CONCLUSIONS}

In terms of climatic chambers, based on regression models obtained in this study, the room temperature values that provide the best performance for the initial period of growth of broilers were $31.3^{\circ} \mathrm{C}$ in the first week, between 26.3 and $27.1^{\circ} \mathrm{C}$ for the second week and between 22.5 and $23.2{ }^{\circ} \mathrm{C}$ for the third week.

\section{ACKNOWLEDMENTS}

To CNPq, CAPES, and the company FAPEMIG Pif-Paf Alimentos S.A.

\section{REFERENCES}

AVILA, V. S. Aspectos importantes a considerar na criação de frangos de corte no período frio. Versão eletrônica, 2004. Disponível em: <http://www.cnpsa.embrapa.br/?artigos/2004/artigo-2004n015.html;ano=2004>. Acesso em: 9 nov. 2010.

BARBOSA, F. J. V.; LOPES, J. B.; FIGUEIRÊDO, A. V.; ABREU, M. L. T.; DOURADO, L. R. B.; FARIAS, L. A.; PIRES, J. E. P. Níveis de energia metabolizável em rações para frangos de corte mantidos em ambiente de alta temperatura. Revista Brasileira de Zootecnia, Viçosa, v.37 n.5, maio 2008.

CARVALHO, J. C. C.; BERTECHINI, A. G.; FASSANI, E. J.; RODRIGUES, P. B.; PEREIRA, R. A. N. Desempenho e características de carcaça de frangos de corte alimentados com dietas à base de milho e farelo de soja suplementadas com complexos enzimáticos. Revista Brasileira de Zootecnia, Viçosa, v.38, n.2, p.292-298, 2009.

COBB. Broiler management guide. Arkansas: Cobb-Vantress USA, 2010. 65 p.

EUCLYDES, R. F. SAEG (Sistema para análise estatística e genéticas). Manual de utilização do programa SAEG. Viçosa: UFV, 2005

FREEMAN, B.M. The fowl and its physical environment. World's Poultry Science Journal, Ithaca, v.25, p.99-111, 1968.

MACARI, M.; FURLAN, R.L.; GONZALES, E. Fisiologia aviária aplicada a frangos de corte. 2.ed. ampl. Jaboticabal: FUNEP/UNESP, 2002.

MAY, J. D.; LOTT, B. D. The effect of environmental temperature on growth and feed conversion of broilers to 21 days of age. Poultry Science, v.79 p.669-671, 2000.

ROCHA, H. P.; FURTADO, D. A.; NASCIMENTO, J. W. B.; SILVA, J. H. V. Índices bioclimáticos e produtivos em diferentes galpões avícolas no semiárido paraibano. Revista Brasileira de Engenharia. Agrícola e Ambiental, Campina Grande, v.14, n.12, dez. 2010.

SILVA, V. K.; SILVA, J. D. T.; GRAVENA, R. A.; MARQUES, R. H.; HADA, F. H.; MORAES, V. M. B. Desempenho de frangos de corte de 1 a 21 dias de idade alimentados com rações contendo extrato de leveduras e prebiótico e criados em diferentes temperaturas. Revista Brasileira de Zootecnia, Viçosa, v.38, n.4, p.690-696, 2009.

SOUZA, M. G.; OLIVEIRA, R. F. M.; DONZELE, J. L.; MAIA, A. P. A.; BALBINO, E. M.; OLIVEIRA, W. P. Utilização das vitaminas $\mathrm{C}$ e E em rações para frangos de corte mantidos em ambiente de alta temperatura. Revista Brasileira de Zootecnia, Viçosa, v.40, n.10, out. 2011.

TINÔCO, I.F.F. A granja de frangos de corte: produção de frangos de corte. Campinas: FACTA, 2004. 356 p. 
VENCATO, A. Z. Anuário brasileiro de aves e suínos. Santa Cruz do Sul: Editora Gazeta Santa Cruz, 2011. 112 p.

WELKER, J. S.; ROSA, A. P.; MOURA, D. J.; MACHADO, L. P.; CATELAN, F.; UTTPATEL, R.Temperatura corporal de frangos de corte em diferentes sistemas de climatização. Revista Brasileira de Zootecnia, Viçosa, v.37 n.8, ago. 2008 